\title{
IMPLEMENTASI KEBIJAKAN PEMILIHAN KEPALA DESA SERENTAK (Studi Kasus di Desa Elfule Kecamatan Namrole Kabupaten Buru Selatan Provinsi Maluku)
}

\author{
Oleh \\ Sugandhi Putra Angkotasan \\ Staf Pemerintah Kabupaten Buru Selatan \\ Mahasiswa Program Pascasarjana Magister Terapan Ilmu Pemerintahan IPDN \\ gandhioryana@gmail.com
}

\begin{abstract}
$T$ The purpose of this study was to determine and analyze the Implementation of the Policy for the Election of simultaneously Village Heads (Case Study in Elfule Village, Namrole District, South Buru Regency, Maluku Province). The research method used in the preparation of this thesis is a descriptive research method, with a qualitative approach. Data obtained through data collection techniques: observation, interviews and documentation. The results of this study indicate that the Implementation of the Policy for the Election of simultaneously Village Heads (Case Study in Elfule Village, Namrole Subdistrict, South Buru Regency, Maluku Province) has not been well seen in terms of: Basic measures and policy objectives refer to the Minister of Home Affairs regulations, regional regulations to choose the elfule village head candidate pair. Policy Sources are supported by human resources and budget. Communication between organizations and implementation activities has not all clearly understood the objectives to be achieved, but in terms of coordination, there has been a connection between the Regional Government of South Rush Regency and the implementation of village head elections. Characteristics of the Agency Implementing human resources policies already exists in terms of the educational background of the majority of undergraduate education but in terms of authority has the authority of each implementing element. Socio-economic and political conditions have a large influence and the public is supportive and not supportive. The tendency of executing disposition in carrying out the policy has the awareness of each officer, but in terms of responsibility, it is still unable to bring the community to participate in the Elfule village head election.
\end{abstract}

Keywords: implementation, policy, election

\section{ABSTRAK}

$\mathrm{T}$ ujuan penelitian ini untuk mengetahui dan menganalisis Implementasi Kebijakan Pemilihan Kepala Desa Serentak (Studi Kasus di Desa Elfule Kecamatan Namrole Kabupaten Buru Selatan Provinsi Maluku). Metode penelitian yang digunakan dalam penyusunan tesis ini adalah metode penelitian deskriptif, dengan pendekatan kualitatif. Data diperoleh melalui teknik pengumpulan data: observasi, wawancara dan dokumentasi. Hasil penelitian ini menunjukkan bahwa Implementasi Kebijakan Pemilihan Kepala Desa Serentak (Studi Kasus di Desa Elfule Kecamatan Namrole Kabupaten Buru Selatan Provinsi Maluku) belum baik hal ini dilihat dari aspek: Ukuran-ukuran dasar dan tujuan kebijakan sudah mengacu kepada peraturan menteri dalam negeri, peraturan daerah untuk memilih pasangan calon kepala 
Desa Elfule. Sumber-Sumber Kebijakan sudah didukung oleh sumber daya manusia dan anggaran. Komunikasi antar- organisasi dan kegiatan-kegiatan pelaksanaan belum semuanya memahami dengan jelas mengenai tujuan yang hendak dicapai namun dari segi koordinasi sudah terjalin antara pemerintah Daerah Kabupaten buru selatan dengan pelaksana pemilihan kepala desa. Karakteristik Badan Pelaksana kebijakan sumber daya manusia sudah ada dari segi latar pendidikan mayoritas pendidikannya sarjana namun dari segi wewenang telah mempunyai kewenangan masing-masing unsur pelaksana. Kondisi-kondisi ekonomi sosial dan politik mempunyai pengaruh yang besar serta publik masyarakat ada yang mendukung dan tidak mendukung. Kecenderungan disposisi pelaksana dalam menjalankan kebijakan telah mempunyai kesadaran masing-masing petugas namun dari segi tanggung jawab masih belum mampu menghadirkan masyarakat agar mengikuti pelaksanaan pemilihan kepala Desa Elfule.

Kata kunci: implementasi, kebijakan, pemilihan

\section{PENDAHULUAN}

$\coprod \mathrm{m}$ mplementasi kebijakan Pemerintah Kabupaten Buru Selatan mengenai penyelenggaraan Pilkades masih banyak menyimpan berbagai permasalahan dalam tahapan pelaksanaan Pilkades, di antaranya pada tahap penjaringan dan penyaringan calon Kades, kurangnya sosialisasi dan komunikasi pihak panitia dengan bakal calon atau masyarakat.

Ketidakvalidan data pemilih tetap hal ini terjadi pada penghitungan suara diketahui adanya selisih jumlah kertas suara dengan jumlah daftar pemilih tetap, penghitungan suara dilakukan semi tertutup karena hanya disaksikan oleh para saksi dari masingmasing pasangan calon Kades. Termasuk adanya panetrasi kepentingan elite politik di desa/tingkat bawah, juga terkait dengan politik uang, sebagai sarana ajang perjudian (pertaruhan), adanya calon yang tidak kapabel/tidak aspiratif maupun rendahnya kemampuan potensi akademik serta terjadinya persaingan yang tidak sehat.

Keberadaan Panitia Pemilihan Tingkat Kabupaten untuk melakukan berbagai upaya guna mencegah terjadinya penyimpangan, intimidasi, suap menyuap, jual beli suara, kampanye negatif dan perjudian dalam pelaksanaan Pilkades.

Sampai saat ini dalam penyelenggaraan Pilkades selalu muncul persoalan klasik seperti terbatasnya anggaran sehingga sarana dan prasaran penunjang menjadi sangat terbatas, dalam perekrutan calon Kades kurang mempertimbangkan kemampuan pendidikan formal pada diri calon Kades.

Berdasarkan hasil wawancara pra penelitian dengan tokoh masyarakat Desa Elfule Kecamatan Namrole saudara Dayan Solissa (wawancara 02 November 2017), menyampaikan persoalan sekitar penyelenggaraan Pilkades yang antara lain mengatakan:

1. Unsur panitia pemilihan tingkat desa adalah Badan Permusyawaratan Desa (BPD) dan Perangkat Desa serta masyarakat yang dibentuk berdasarkan keputusan BPD Desa Elfule. Namun, perda tidak mengatur tata cara dan syarat-syarat sebagai Panitia pemilihan di tingkat desa, mekanisme pembentukan, pertanggungjawaban panitia, serta kode etik sebagai penyelenggara pilkades. Sehingga terjadi varian panitia pemilihan kepala desa. Dan dalam menjalankan tugasnya panitia kurang independen, jujur dan adil.

2. BPD Desa Elfule, memiliki otoritas yang terlalu besar, di antaranya adalah dalam penyaringan bakal calon, pengesahan calon terpilih dan usul pembatalan hasil pemilihan kepala desa. Kedudukan, tugas dan fungsi BPD tumpang tindih 
dengan panitia pemilihan kepala desa. Sehingga melahirkan ketidakpastian dan kejelasan terhadap BPD maupun Panitia pemilihan itu sendiri.

3. Perda tidak mengatur secara detail tentang kampanye. Padahal, kampanye merupakan bagian dari tahapan pelaksanaan Pilkades dan dalam praktiknya selama ini telah berlangsung kampanye Pilkades. Dengan tidak diaturnya kampanye, maka pelaksanaan kampanye tidak memiliki rambu-rambu yang jelas, dan ketidakjelasan inilah yang seringkali memicu terjadinya konflik dan kerawanan sosial.

4. Pendaftaran pemilih. Perda tidak menjabarkan pendataan dan penetapan pemilih. Syarat pemilih rancu, khususnya menyangkut persyaratan domisili selama 6 bulan secara terusmenerus. Penafsiran ketentuan ini sangat beragam di semua desa. Sehingga, dalam implementasinya pendataan dan pendaftaran pemilih sangat bervariasi. Dan kondisi ini menjadi salah satu pemicu terjadinya masalah dalam pendataan dan pendaftaran pemilih.

5. Penyelesaian Sengketa Pilkades. Perda tidak mengatur secara jelas Panitia Pemilihan Tingkat Kabupaten ataukah lembaga yang berwenang dalam penyelesaian sengketa Pilkades, tata cara pengajuan keberatan hasil Pilkades, maupun kriteria pelanggaran Pilkades. Dalam Perda, pembatalan hasil Pilkades dilaksanakan oleh Bupati atas usul BPD. Persoalannya, indikator yang digunakan sebagai tolok ukur terlalu umum yakni pelanggaran terhadap asas langsung, umum, bebas, rahasia, jujur dan adil. Akibatnya, makna pelanggaran melahirkan multi-interpretasi dan penilaian cenderung bersifat subjektif, yang mengakibatkan tidak ada kepastian dan keadilan yang objektif dalam penyelesaian sengketa Pilkades.
6. Pembiayaan Pemilihan Kepala Desa Elfule. Biaya pemilihan Kepala Desa selama ini, dibebankan pada APBDes. Padahal, hampir sebagian besar APBDes Elfule mengalami keterbatasan untuk membiayai Pilkades. Terbatasnya anggaran tersebut menyebabkan sejumlah tahapan pelaksanaan Pilkades tidak dapat berjalan maksimal. Bahkan, sejumlah desa terpaksa menunda pelaksanaan Pilkades karena tidak tersedianya anggaran.

7. Penjaringan Bakal Calon, Penyaringan dan Kriteria/syarat calon kepala desa. Proses penjaringan Bakal Calon dilaksanakan oleh Panitia Pilkades, namun proses penyaringan Bakal Calon untuk menjadi Calon dilaksanakan oleh BPD. Pada saat proses penjaringan Bakal Calon, Panitia Pilkades menerima berkas administratif (syarat formal) Bakal Calon Kepala Desa dan diserahkan kepada BPD. BPD kemudian melakukan proses penyaringan Bakal Calon. Perda tidak mengatur tata cara penilaian dan indikator penilaian sebagai barometer BPD untuk melakukan seleksi. Dalam ketentuan Perda, hanya memberikan saran berupa pertimbangan agar BPD dalam melaksanakan proses penyaringan mempertimbangkan visi dan misi, kemampuan dan kepribadian Bakal Calon. Kriteria inilah yang kemudian dijadikan sebagai landasan BPD untuk melaksanakan penyaringan bakal calon. Padahal, kriteria tersebut selama ini bersifat subjektif dan indikator yang digunakan tidak jelas.

Daftar Pemilih Tetap dan Partisipasi Politik Masyarakat Pemilihan Kepala Desa Elfule 2016 dapat dilihat pada tabel berikut. 
Tabel 1 Daftar Pemilih Tetap dan Partisipasi Politik Masyarakat Pemilihan Kepala Desa Elfule 2016

\begin{tabular}{ccccccc}
\hline & & \multicolumn{3}{l}{ Jumlah Pemilih } & Partisipasi \\
\cline { 3 - 6 } No & TPS & $\mathbf{L}$ & $\mathbf{P}$ & Total & $\begin{array}{c}\text { Politik } \\
\text { Masyarakat }\end{array}$ & \% \\
\hline 1 & TPS 1 & 258 & 256 & 514 & 360 & 70,04 \\
\hline 2 & TPS 2 & 237 & 239 & 476 & 314 & 65,97 \\
\hline 3 & TPS 3 & 216 & 236 & 452 & 216 & 47,79 \\
\hline 4 & TPS 4 & 192 & 181 & 373 & 281 & 75,33 \\
\hline \multicolumn{2}{l}{ Total } & 903 & 912 & 1.815 & 1.171 & 64,52 \\
\hline
\end{tabular}

Sumber: Panitia Pemilihan Kepala Desa Elfule

Berdasarkan tabel di atas menunjukkan bahwa daftar pemilih tetap Desa Elfule dari 4 Tempat Pemungutan Suara di ikuti oleh daftar pemilih tetap laki-laki sebanyak 903 orang dan Perempuan sebanyak 912 orang sehingga total keseluruhannya sebanyak 1.815 orang. Namun dalam pelaksanaannya pemilihan Kepala Desa Elfule Tahun 2016 untuk partisipasi politik masyarakat sebesar 1171 orang atau $64,52 \%$.

Dari data tersebut ada masyarakat Desa Elfule yang tidak ikut partisipasi politik dalam pemilihan kepala Desa Elfule sebanyak 35,48 \%. Pelaksanaan Pemilihan Kepala Desa Elfule Tahun 2016 dengan hasil perolehan hasil suara calon kepala Desa sebagai berikut.

Tabel 2 Hasil Perolehan Suara Pemilihan Kepala Desa Elfule Tahun 2016

\begin{tabular}{cccc}
\hline No & Nama Calon & $\begin{array}{c}\text { Jumlah } \\
\text { Surat Suara }\end{array}$ & \multicolumn{1}{c}{$\%$} \\
\hline 1 & $\begin{array}{l}\text { Samatut } \\
\text { Titawael }\end{array}$ & 501 & 42,78 \\
\hline 2 & Jufri Titawael & 670 & 57,22 \\
\hline & Jumlah & 1.171 & 100.00 \\
\hline
\end{tabular}

Sumber: Panitia Pemilihan Kepala Desa Elfule

Data tabel di atas menunjukkan nama calon Samatut Titawael memperoleh jumlah surat suara 501 surat suara atau 42,78\% dan Jufri Titawael memperoleh jumlah surat suara 670 surat suara atau 57,22\%. Sehingga yang memenangkan Pemilihan Kepala Desa Elfule Tahun 2016 adalah Jufri Tatawael dengan unggul jumlah suara sebesar 670 atau $57,22 \%$.

\section{METODE PENELITIAN}

Pendekatan yang dilakukan dalam penelitian ini adalah pendekatan kualitatif. Penelitian kualitatif tersebut dipilih dengan pertimbangan bahwa dengan melalui penelitian kualitatif diharapkan akan mampu mengkaji masalah penelitian secara mendalam, sehingga dapat memperoleh dan mempermudah penjelasan yang bermakna. Pendapat mengenai penelitian kualitatif dikemukakan oleh Sugiyono (2013: 1) yaitu:

Metode penelitian kualitatif adalah metode penelitian yang digunakan untuk meneliti pada kondisi objek yang alamiah, (sebagai lawannya adalah eksperimen) di mana peneliti adalah sebagai instrumen kunci, teknik pengumpulan data dilakukan secara triangulasi (gabungan), analisis data bersifat induktif/kualitatif, dan hasil penelitian kualitatif lebih menekankan makna dari pada generasi.

Alasan peneliti menggunakan metode deskriptif dengan pendekatan kualitatif dalam penelitian ini agar peneliti dapat mengetahui secara jelas tentang Implementasi Kebijakan Pemilihan Kepala Desa Serentak (Studi Kasus di Desa Elfule Kecamatan Namrole Kabupaten Buru Selatan Provinsi Maluku). Dalam penelitian ini peneliti berusaha mendeskripsikan keadaan suatu objek penelitian kemudian dibahas untuk mendapatkan simpulan umum serta pemahaman terhadap objek tersebut.

Teknik pengumpulan data yang digunakan oleh peneliti dalam penelitian ini yaitu:

1. Wawancara

Dalam penelitian ini peneliti menggunakan wawancara semi terstruktur yang dilakukan secara mendalam kepada Bupati Kabupaten Buru Selatan Kepala Bagian Tata Pemerintahan Kabupaten Buru Selatan, Camat Namrole, Ketua Badan 
Permusyawaratan Desa Elfule, Panitia Pemilihan Kepala Desa dan Masyarakat Desa Elfule.

2. Observasi/pengamatan

Obervasi yang penulis lakukan mendatangi kantor Kepala Desa dan Masyarakat Desa Elfule.

3. Dokumentasi

Dokumentasi yang penulis lakukan terhadap Undang-Undang Nomor 6 Tahun 2014 tentang Desa, Peraturan Pemerintah Nomor 43 Tahun 2014 tentang Peraturan Pelaksanaan UndangUndang Nomor 6 Tahun 2014 tentang Desa, Peraturan Menteri Dalam Negeri Nomor 112 Tahun 2014 tentang Pemilihan Kepala Desa, Peraturan Daerah Kabupaten Buru Selatan Nomor 21 Tahun 2015 tentang Tata cara Pencalonan, Pemilihan, Pelantikan dan Pemberhentian Kepala Desa, Keputusan Bupati Buru Selatan Nomor 24 Tahun 2016 tentang Tahapan, Program dan jadwal penyelenggaraan Pemilihan Kepala Desa Serentak di Kabupaten Buru Selatan Tahun 2016, Daftar Pemilih Tetap Desa Elfule.

Lokasi penelitian di Lokasi penelitian dilakukan di Desa Elfule Kecamatan Namrole Kabupaten Buru Selatan Provinsi Maluku.

\section{LANDASAN TEORETIS}

Dalam konteks penelitian ini konsepyang digunakan untuk mengukur implementasi kebijakan peneliti menggunakan teori implementasi kebijakan yang dikemukakan oleh Van Meter dan Van Horn dalam Winarno (2012: 159-168) meliputi:

1) Ukuran-ukuran dasar dan tujuan-tujuan kebijakan.

2) Sumber-sumber kebijakan.

3) Komunikasi antar- organisasi dan kegiatan-kegiatan pelaksanaan.

4) Karakteristik badan-badan pelaksana.
5) Kondisi-kondisi ekonomi sosial dan politik.

6) Kecenderungan pelaksana (implementors).

Mencermati model Van Meter dan Van Horn maka dapat dipahami bahwa keunikan model tersebut pada pemahaman yang komprehensif akan konteks kebijakan.

\section{HASIL PENELITIAN DAN PEMBAHASAN}

\section{IMPLEMENTASI KeBIJAKAN PEMILIHAN Kepala Desa Serentak di Desa Elfule}

Ukuran-Ukuran Dasar dan Tujuan Kebijakan:

a) Ukuran Dasar Kebijakan tentang Pemilihan Kepala Desa Serentak di Desa Elfule Kecamatan Namrole

Ukuran dasar kebijakan tentang pemilihan kepala desa serentak di Desa Elfule Kecamatan Namrole mengacu kepada Permendagri Nomor 112 Tahun 2014 tentang Pemilihan Kepala Desa; Peraturan Daerah Kabupaten Buru Selatan Nomor 21 Tahun 2015 tentang Tata Cara Pencalonan, Pemilihan, Pelantikan, Dan Pemberhentian Kepala Desa. Keputusan Bupati Buru Selatan Nomor 24 Tahun 2016 tentang Tahapan, Program dan jadwal penyelenggaraan Pemilihan Kepala Desa Serentak Di Kabupaten Buru Selatan Tahun 2016.

b) Tujuan Kebijakan tentang Pemilihan Kepala Desa Serentak di Desa Elfule Kecamatan Namrole

Tujuan kebijakan tentang pemilihan kepala desa serentak di Desa Elfule Kecamatan Namrole memilih pasangan calon kepala Desa Elfule dan lancarnya pelaksanaan tugasnya dari awal sampai akhir pelaksanaan pemilihan kepala desa dalam melaksanakan pemilihan kepala desa serentak di Desa Elfule Kabupaten Buru Selatan. 


\section{b. Sumber Kebijakan}

a) Sumber Daya Manusia Pemilihan Kepala Desa Serentak di Desa Elfule Kecamatan Namrole

Sumber Daya Manusia Pemilihan Kepala Desa Serentak di Desa Elfule Kecamatan Namrole cukup baik. Hal ini bisa dilihat dari keradaan sumber daya manusia Panitia Pemilihan Kepala Desa Elfule Tahun 20168 orang merupakan lulusan sarjana.

b) Anggaran Pemilihan Kepala Desa Serentak di Desa Elfule Kecamatan Namrole

Anggaran Pemilihan Kepala Desa Serentak di Desa Elfule Kecamatan Namrole cukup baik. Hal ini bisa dilihat dari ketersediaannya anggaran pemilihan kepala Desa Elfule yang mencapai $\mathrm{Rp} 104$. $720.000,00$.

c. Komunikasi antar- organisasi dan kegiatan-kegiatan pelaksanaan

a) Kejelasan tentang Pemilihan Kepala Desa Serentak di Desa Elfule Kecamatan Namrole

Kejelasan tentang pemilihan Kepala Desa Serentak di Desa Elfule Kecamatan Namrole belum semuanya memahami dengan jelas mengenai tujuan yang hendak dicapai dalam implementasi kebijakan dalam pemilihan kepala Desa Elfule. Selama ini, masyarakat menganggap menjadi panitia pemilihan kepala desa memerlukan pengorbanan yang besar baik waktu, tenaga, barang dan uang tugas panitia pemilihan kepala desa adalah tugas sosial karena tidak mendapatkan gaji bahkan pekerjaan dirumah maupun di Kantor terkadang dikorbankan untuk beberapa saat. b) Koordinasi dalam Pemilihan Kepala Desa Serentak di Desa Elfule Kecamatan Namrole

Koordinasi dalam pemilihan kepala desa Serentak di Desa Elfule Kecamatan Namrole sudah terjalin antara pemerintah Kabupaten Buru Selatan melalui bagian tata pemerintahan dan camat sebagai pengawas/pendamping terhadap pelaksana lapangan Badan Permusyawaratan Desa Elfule dan panitia pemilihan kepala Desa Elfule.

\section{d. Karakteristik Badan Pelaksana}

a) Sumberdaya/Tenaga Pelaksana Pemilihan Kepala Desa di Desa Elfule Kecamatan Namrole

Sumber Daya Manusia Pelaksana dalam pemilihan kepala desa serentak khususnya di Desa Elfule sudah ada, mereka didukung pendidikan yang mumpuni karena mayoritas pendidikannya Sarjana kemudian dalam tahap penjaringannya mengalami kesulitan karena masyarakat Desa Elfule mempunyai persepsi menjadi panitia pemilihan kepala Desa Elfule hanya akan memerlukan pengorbanan yang besar baik waktu, tenaga, barang dan uang tugas panitia pemilihan kepala desa adalah tugas sosial karena tidak mendapatkan gaji bahkan pekerjaan dirumah maupun di Kantor terkadang dikorbankan untuk beberapa saat.

b) Wewenang Dalam Pemilihan Kepala Desa serentak di Desa Elfule Kecamatan Namrole

Wewenang dalam pemilihan kepala Desa serentak di Desa Elfule Kecamatan Namrole telah mempunyai kewenangan masing- 
masing unsur pelaksana antara lain pemerintah daerah Kabupaten Buru Selatan melalui bidang tata pemerintahan dan kecamatan Namrole, Badan Permusyawaratan Desa dan panitia pemilihan kepala Desa Elfule.

e. Kondisi-Kondisi Ekonomi Sosial Dan Politik

a) Lingkungan Eksternal Kondusif Dalam Pelaksanaan Pemilihan Kepala Desa Serentak di Desa Elfule Kecamatan Namrole

Kondisi lingkungan eksternal bidang Ekonomi dan politik dalam pemilihan kepala Desa Elfule menjadi pengaruh yang besar dalam masyarakat Elfule yang berharap dengan terpilihnya kepala desa baru mudah-mudahan dapat merubah perekonomian kehidupan masyarakat lingkungan Desa Elfule Kecamatan Namrole ke arah yang lebih baik.

b) Dukungan Publik tentang Pemilihan Kepala Desa Serentak di Desa Elfule Kecamatan Namrole

Dukungan publik tentang pemilihan kepala desa serentak Di Desa Elfule Kecamatan Namrole ada dua pendapat yang diungkapkan dari kalangan masyarakat antara mendukung dan tidak mendukung Oleh karena itu kebijakan publik merupakan suatu fenomena yang kompleks karena ada berbagai variasi dukungan yang melibatkan beragam kepentingan di mana masing-masing pihak mencermati kebijakan dari perspektifnya masing-masing. Mengingat kompleksitas dari kebijakan publik, maka seharusnya pemerintah sebagai pihak yang memiliki kewenangan untuk mengambil keputusan dan melaksanakannya dituntut untuk mampu menjalankan keputusan secara tepat dengan berorientasi pada sebesar mungkin dari kepentingan masyarakat agar mendapat dukungan.

f. Kecenderungan

pelaksana (implementors)

a) Komitmen dalam pelaksanaan pemilihan kepala desa Serentak di Desa Elfule Kecamatan Namrole

Komitmen dalam pelaksanaan pemilihan kepala desa Serentak di Desa Elfule Kecamatan Namrole sudah ada. Hal ini terlihat dari komitmen kepatuhan panitia pemilihan kepala Desa Elfule dalam pelaksanaan kebijakan tergantung pada kesadaran masing-masing aparatur karena ini disebabkan oleh regulasi yang mengatur kebijakan tersebut.

b) Tanggung Jawab Dalam Melaksanakan Pemilihan Kepala Desa Serentak di Desa Elfule Kecamatan Namrole

Tanggung jawab dalam melaksanakan pemilihan kepala desa serentak di Desa Elfule Kabupaten Buru Selatan sudah baik namun dari segi pelaksanaan masih belum mampu menghadirkan masyarakat agar mengikuti pelaksanaan pemilihan kepala Desa Elfule.

\section{FAKTOR-FAKTOR YANG MENJADI HAMBATAN}

a. Panitia Pemilihan Kepala Desa Kurang diminati

Menjadi Panitia Pemilihan Kepala Desa Elfule Kurang diminati hal ini dikarenakan pemikiran masyarakat Desa Elfule yang kurang positif, mereka 
mempunyai persepsi menjadi panitia pemilihan kepala Desa Elfule hanya dilihat dari sisi materi bukan dilihat dari kesadaran menjadi warga negara yang siap mengabdikan diri untuk kepentingan umum dan bangsa.

b. Tingginya Biaya Pendaftaran untuk Calon Kepala Desa

Tingginya biaya untuk pendaftaran Calon Kepala Desa Elfule menyebabkan kurang diminati pendaftaran calon kepala Desa Elfule hal ini menyebabkan sedikitnya yang daftar menjadi calon kepala Desa Elfule sehingga hanya dari masyarakat yang ekonominya sudah mapan sepkaerti pedagang, pekerja tambang dan peternak yang mendaftar.

\section{Mengatasi faktor Penghambat}

1. Perencanaan

Dalam pelaksanaan kegiatan Pemilihan Kepala Desa Serentak di Desa Elfule perencanaan perlu adanya kemampuan untuk menyusun stategi baik

2. Pengorganisasian

Dalam rangka pelaksanaan Pemilihan Kepala Desa Serentak di Desa Elfule perlu adanya pengorganisasian sehingga akan dapat ditentukan secara pasti, siapa berbuat apa, siapa bekerja sama dengan siapa serta bertanggung jawab kepada siapa, dengan tanpa melupakan prinsip-prinsip dalam pengorganisasian

3. Pelaksanaan.

Dalam pelaksanaan Pemilihan Kepala Desa Serentak di Desa Elfule tentunya berpedoman pada hal-hal yang sudah direncanakan.

4. Pengendalian.

Guna keberhasilan pelaksanaan tugas di lapangan dan agar rencana yang sudah ditetapkan dalam Pemilihan Kepala Desa Serentak di Desa Elfule dapat berjalan sebagaimana mestinya perlu adanya suatu pengendalian

\section{SIMPULAN DAN SARAN}

\section{SIMPULAN}

1. Implementasi Kebijakan Pemilihan Kepala Desa Serentak di Desa Elfule Kecamatan Namrole Kabupaten Buru Selatan Provinsi Maluku belum baik hal ini dilihat dari aspek:

a. Ukuran-ukuran dasar dan tujuan kebijakan pemilihan kepala desa serentak di Desa Elfule Kecamatan Namrole mengacu kepada Permendagri Nomor 112 Tahun 2014 tentang Pemilihan Kepala Desa; Peraturan Daerah Kabupaten Buru Selatan Nomor 21 Tahun 2015 tentang Tata Cara Pencalonan, Pemilihan, Pelantikan, Dan Pemberhentian Kepala Desa. Keputusan Bupati Buru Selatan Nomor 24 Tahun 2016 tentang Tahapan, Program dan jadwal penyelenggaraan Pemilihan Kepala Desa Serentak Di Kabupaten Buru Selatan Tahun 2016 dan tujuannya memilih pasangan calon kepala Desa Elfule dan lancarnya pelaksanaan tugasnya dari awal sampai akhir pelaksanaan pemilihan kepala desa dalam melaksanakan pemilihan kepala desa serentak di Desa Elfule Kabupaten Buru Selatan.

b. Sumber-Sumber Kebijakan Pemilihan Kepala Desa Serentak di Desa Elfule Kecamatan Namrole cukup baik. Hal ini bisa dilihat dari keradaan sumber daya manusia Panitia Pemilihan Kepala Desa Elfule Tahun 2016 yang merupakan lulusan sarjana kemudian ketersediaannya anggaran pemilihan kepala Desa Elfule yang mencapai Rp 104. $720.000,00$.

c. Komunikasi antar- organisasi dan kegiatan-kegiatan pelaksanaan 
dalam Pemilihan Kepala Desa Serentak di Desa Elfule Kecamatan Namrole Kabupaten Buru Selatan Provinsi Maluku belum semuanya memahami dengan jelas mengenai tujuan yang hendak dicapai dan masyarakat menganggap menjadi panitia pemilihan kepala desa memerlukan pengorbanan yang besar baik waktu, tenaga, barang dan uang namun dari segi koordinasi sudah terjalin antara pemerintah Kabupaten Buru Selatan melalui bagian tata pemerintahan dan camat sebagai pengawas/pendamping terhadap pelaksana lapangan Badan Permusyawaratan Desa Elfule dan panitia pemilihan kepala Desa Elfule.

d. Karakteristik Badan Pelaksana dalam Pemilihan Kepala Desa Serentak di Desa Elfule Kecamatan Namrole Kabupaten Buru Selatan Provinsi Maluku sumber daya manusia sudah ada dilihat dari segi latar pendidikan yang cukup mumpuni karena mayoritas pendidikannya lulusan sarjana namun dari segi wewenang telah mempunyai kewenangan masingmasing unsur pelaksana.

e. Kondisi-kondisi ekonomi sosial dan politik dalam menjalankan kebijakan dalam Pemilihan Kepala Desa Serentak di Desa Elfule Kecamatan Namrole Kabupaten Buru Selatan Provinsi Maluku kondisi lingkungan eksternal mempunyai pengaruh yang besar dalam masyarakat Elfule yang berharap dengan terpilihnya kepala desa dapat merubah perekonomian kehidupan masyarakat lingkungan Desa Elfule Kecamatan Namrole ke arah yang lebih baik serta Publik masyarakat ada yang mendukung dan tidak mendukung. f. Kecenderungan pelaksana (implementors) dalam menjalankan kebijakan Pemilihan Kepala Desa Serentak di Desa Elfule Kecamatan Namrole Kabupaten Buru Selatan Provinsi Maluku sudah ada komitmen kepatuhan panitia pemilihan kepala Desa Elfule dari kesadaran masingmasing petugas namun dari segi tanggung jawab masih belum mampu menghadirkan masyarakat agar mengikuti pelaksanaan pemilihan kepala Desa Elfule.

2. Faktor-faktor yang menjadi hambatan Implementasi Kebijakan Pemilihan Kepala Desa Serentak (Studi Kasus di Desa Elfule Kecamatan Namrole Kabupaten Buru Selatan Provinsi Maluku) antara lain: Panitia Pemilihan Kepala Desa Kurang diminati dan Tingginya Biaya Pendaftaran untuk Calon Kepala Desa.

3. Upaya mengatasi faktor penghambat Implementasi Kebijakan Pemilihan Kepala Desa Serentak (Studi Kasus di Desa Elfule Kecamatan Namrole Kabupaten Buru Selatan Provinsi Maluku) melalui perencanaan, pengorganisasian, pelaksanaan dan pengendalian.

\section{SARAN}

1. Teoretis

Perlu dikaji secara mendalam mengenai Implementasi kebijakan pemilihan kepala desa serentak.

2. Praktis

a. Pemerintah Daerah Kabupaten Buru Selatan sebaiknya melakukan pengawasan dan pembinaan langsung terhadap Desa Elfule dalam melaksanakan pemilihan kepala Desa.

b. Camat Namrole sebaiknya melakukan pengawasan dan 
pembinaan langsung terhadap Badan Permusyawaratan Desa Elfule dalam merekrut panitia pemilihan kepala Desa Elfule.

c. Badan Permusyawaratan Desa Elfule sebaiknya banyak menyosialisasikan ke tiap RW dan RT mengenai perekrutan panitia pemilihan kepala Desa Elfule.

Panitia pemilihan kepala Desa Elfule sebaiknya melakukan pelatihan kerja guna untuk memperbaiki penguasaan terhadap teknik pelaksanaan kerja.

\section{DAFTAR PUSTAKA}

Agus, Sunyoto. 2008. Manajemen Sumber Daya Manusia. Jakarta: Badan Penerbit IPWI.

Agustino, Leo, 2008. Dasar-dasar Kebijakan Publik. Bandung: Alfabeta.

Arikunto, Suharsimi, 2010, Prosedur Penelitian Suatu Pendekatan Praktik, Jakarta: Rineka Cipta.

Basrowi \& Suwandi. 2008. Memahami Penelitian Kualitatif. Jakarta: Rineka Cipta.

Collins, P.H. Dictionary of Politics and Government. (London: Bloomsbury, 2004).

Dadang, 2003. Politik Pemberdayaan (Jalan Menuju Otonomi Desa), Pondok Pustaka Jogja, Yogyakarta.

Dunn, William, 2003. Pengantar Analisis Kebijakan Publik Edisi Ketiga. Yogya kar ta: Gadjah Mada University Press.

Geertz Clifford. 1992. Tafsir Kebudayaan. Yogyakarta Penerbit Kanisius.

Hoogerwerf. 1978. Ilmu Pemerintahan. Jakarta: Erlangga.

Islamy, Irfan, 2007. Prinsip-prinsip Perumusan Kebijaksanaan Negara. Jakarta: Bumi Aksara.

Ismawan, Indra. 2002. Ranjau-Ranjau Otonomi Daerah. Pondok Edukasi, Solo.

Kusumanegara, Solahudin. 2010. Model dan Aktor Dalam Proses Kebijakan Publik. Yogyakarta: Penerbit Gava Media.
Lwin, May. \& Aitchison, Jim. (2005). Clueless In Advertising. Jakarta. Bhuana Ilmu Populer, Kelompok Gramedia.

Mathis, R.L. \& J.H. Jackson. 2006. Human Resource Management: Manajemen Sumber Daya Manusia. Terjemahan Dian Angelia. Jakarta: Salemba Empat.

Mangkunegara Anwar Prabu (2002), Manajemen Sumber Daya Manusia, Bandung: PT. Remaja Rosda Karya,

Mazmanian, Daniel, Paul A. Sabatier.1983. Implementation and Public Policy. New York: Harper Collins.

Meter, Donald Van, dan Carl Van Horn, 1975. The Policy Implementation Process: A Conceptual Framework.

Moleong, Lexy J. 2002. Metodologi Penelitian Kualitatif. Bandung: PT $\mathrm{R}$ e $\mathrm{m} \mathrm{a} \mathrm{j}$ a Rosdakarya.

Mustopadidjaya (2002), Manajemen Proses Kebijakan Publik, Formulasi, Implementasi dan Evaluasi Kinerja, Jakarta:LAN.

Nazir, Muhammad 2011. Metode Penelitian. Jakarta: Ghalia Indonesia.

Ndraha, Taliziduhu. 1997. Budaya Organisasi. Jakarta: Rineka Cipta

Nugroho. Riant. 2011. Public Policy. Jakarta: PT Elex Media Computindo.

Subarsono. 2011. Analisis Kebijakan Publik. Yogyakarta: Pustaka Pelajar.

Sugiyono. 2013. Metode Penelitian Kuantitatif Kualitatif dan R\&D. Bandung: CV.Alfabeta.

Suhartono. 2001. Politik Lokal Parlemen Desa. Yogyakarta: Lapera Pustaka Utama.

Sunggono, Bambang (1994). Hukum dan Kebijaksanaan Publik, Jakarta: Sinar Grafika.

Syaodih, Sukmadinata Nana. 2007. Metode Penelitian Pendidikan. Bandung: Rosdakarya.

Tahjan,H, 2008, Implementasi Kebijakan Publik, Bandung: RTH.

Tjokroamidjojo, Bintoro, 1994, Perencanaan Pembangunan, Jakarta: CV. Haji Masagung. 
Umar, Husein. 2010, Desain Penelitian Manajemen Strategik. PT. Jakarta: Raja Grafindo Persada.

Veithzal, Rivai, 2008. Manajemen Sumber Daya Manusia untuk Perusahaan. Jakarta: PT. Raja Grafindo Persada.

Wahab, Abdul, Solichin. 2010. Analisis Kebijaksanaan. Jakarta: PT Bumi Aksara.

Widjaja, HAW. 2008. dimensi-dimensi pemerintahan desa. Jakarta: Bumi Aksara.

Winarno. 2012. Kebijakan Publik, Teori, Proses, dan Studi Kasus edisi \& Revisi Terbaru. Yogyakarta: CAPS.

\section{Peraturan Perundang-undangan}

Undang-Undang Dasar Negara Republik Indonesia Tahun 1945.

Undang-Undang Nomor 5 Tahun 1979 tentang Pemerintahan Desa.

Undang-Undang Nomor 32 Tahun 2004 tentang Pemerintahan Daerah.
Undang-Undang Nomor 23 Tahun 2014 tentang Pemerintahan Daerah.

Undang-Undang Nomor 6 Tahun 2014 tentang Desa.

Peraturan Pemerintah Nomor 43 Tahun 2014 tentang Peraturan Pelaksanaan UndangUndang Nomor 6 Tahun 2014 tentang Desa.

Peraturan Menteri Dalam Negeri Nomor 112 Tahun 2014 tentang Pemilihan Kepala Desa

Peraturan Daerah Kabupaten Buru Selatan Nomor 21 Tahun 2015 tentang Tata Cara Pencalonan, Pemilihan, Pelantikan, dan Pemberhentian Kepala Desa.

Peraturan Daerah Kabupaten Buru Selatan Nomor 130/166 Tahun 2016 tentang Badan Permusyawaratan Desa.

\section{Sumber Lain}

Artikel http://rumahstudio.com/2016/11/07/ sejarah-pilkades-dahulu-dan sekarang/ 